\title{
PENGARUH MANAJEMEN KESISWAAN TERHADAP HASIL BELAJAR MATA PELAJARAN SKI SISWA KELAS VIII E MTSN SAMBIREJO BANYUWANGI TAHUN PELAJARAN 2016/2017
}

\author{
Ribut Suprapto \\ Institut Agama Islam Darussalam (IAIDA) Banyuwangi \\ Email: ributsuprapto@gmail.com
}

\begin{abstract}
This research is directed to 3 main points, that is (1) How is the application of student management of VIII E class student in MTsN Sambirejo in academic year 2016/2017? (2) How is the result of learning of VIIIE class student of MTsN Sambirejo of academic year 2016/2017? (3) Is there an influence of student management application to student learning result of class VIII E MTsN Sambirejo year lesson 2016/2017? (4) How big is the influence of student management application to student learning result of class VIII E MTsN Sambirejo academic year 2016/2017 ?. This research uses the quantitative descriptive method with product moment technique. Popoulasi this research is a student of class VIII E MTsN Sambirejo which amount to 33. After doing an analysis of data collected found that (1) Influence Application of student management in MTsN Sambirejo good. (2) The result of the influence of student management application in class VIII E MTSN Sambirejo good. (3) Influence of student management application to learning result VIII E at MTsN Sambirejo exist. (4) the influence of student management implementation on student learning result of class VIII E at MTsN Sambirejo equal to 19,1\%
\end{abstract}

\section{Key Words: Student Management, Learning Outcomes}

\begin{abstract}
Abstrak
Penelitian ini diarahkan pada 3 hal pokok, yaitu (1) Bagaimana penerapan manajemen kesiswaan siswa kelas VIII E di MTsN Sambirejo tahun pelajaran 2016/2017? (2) Bagaimana hasil belajar siswa kelas VII IE MTsN Sambirejo tahun pelajaran 2016/2017? (3) Adakah pengaruh penerapan manajemen kesiswaan terhadap hasil belajar siswa kelas VIII E MTsN Sambirejo tahun pelajaran 2016/2017? (4) Seberapa besar pengaruh penerapan manajemen kesiswaan terhadap hasil belajar siswa kelas VIII E MTsN Sambirejo tahun pelajaran 2016/2017?. Penelitian ini menggunakan metode deskriptif kuantitatif dengan teknik product moment. Popoulasi penelitian ini adalah siswa kelas VIII E MTsN Sambirejo yang berjumlah 33. Setelah melakukan analisis data yang dikumpulkan, ditemukan bahwa (1) Pengaruh Penerapan manajemen kesiswaan di MTsN Sambirejo baik. (2) Hasil pengaruh penerapan manajemen kesiswaan di kelas VIII E MTSN Sambirejo baik. (3) Pengaruh penerapan manajemen kesiswaan terhadap hasil belajar VIII E di MTsN Sambirejo ada. (4) pengaruh penerapan manajemen kesiswaan terhadap hasil belajar siswa kelas VIII E di MTsN Sambirejo sebesar 19,1\%
\end{abstract}

Kata Kunci : Manajemen Kesiswaan, Hasil Belajar 
Jurnal Darussalam; Jurnal Pendidikan, Komunikasi dan Pemikiran Hukum Islam

Vol. IX, No 1: 184-197. September 2017. ISSN: 1978-4767 (Cetak), ISSN: 2549-4171 (Online)

\section{A. Latar Belakang}

Manajemen Kesiswaan adalah suatu proses pengurusan segala hal yang berkaitan dengan siswa di suatu sekolah mulai dari perencanaan, penerimaan siswa pembinaan yang dilakukan selama siswa berada di sekolah, sampai dengan siswa menyelesaikan pendidikannya di sekolah melalui penciptaan suasana pembelajaran yang kondusif terhadap berlangsungnya proses belajar mengajar atau pembelajaran yang efektif. Hal ini sesuai dengan pendapat yang dikemukakan oleh Mulyasa yang dikutip oleh sulistyorini dan Fathurrohman (2014:168) "Manajemen kesiswaan merupakan salah satu bidang oprasional dalam pengelolaan sekolah. Manajemen kesiswaan adalah penataan dan pengaturan terhadap kegiatan yang berkaitan dengan peserta didik mulai masuk sampai dengan keluarnya peserta didik tersebut dari suatu sekolah". Menurut Suprijono (dalam Thobroni 2016:20) menyatakan bahwa "Hasil belajar adalah pola-pola, perbuatan, nilai-nilai, pengertian-pengertian, sikapsikap, presiasi dan keterampilan. Menurut Bloom hasil belajar mencangkup kemampuan ranah kognitif, ranah efektif dan ranah psikomotorik.

Pentingnya manajemen yang efektif dalam organisasi pendidikan semakin banyak mendapatkan pengakuan dari bergagai pihak. Sekolah, madrasah, dan perguruan tinggi akan lebih efektif dalam memberikan pendidikan yang baik pada siswa atau mahasiswanya, jika mereka termanage dengan baik. Penelitian tentang efektifitas sekolah dan perbaikan sekolah dibeberapa negara menunjukkan bahwa mutu kepemimpinan dan manajemen merupakan salah satu variabel terpenting untuk membedakan antara sekolah yang berhasil dan tidak. Temuan ini menunjukan bahwa manajemen tidak bisa dianggap sebagai suatu aspek intitusi pendidikan yang jumud dan tidak bisa diubah. Manajemen yang baik akan membuat sebuah perbedaan mutu sekolah, madrsah, dan perguruan tinggi, serta kualitas proses pendidikan yang ada didalamnya.

Dimnoc dalam Sulistyorini dan Fathurrohman (2014:9) menyatakan bahwa "Managemen is knowing where you want to go shalt you must avoid what the forces are with to which you must deal, and how to hadle your ship, your crew affectivelly and without waste, in the process of getting there”. 
Oleh karena itu, Manajemen kesiswaan ini merupakan pelayanan yang memusatkan perhatiannya kepada pengaturan, pengawasan serta pelayanan terhadap siswa, baik didalam maupun diluar kelas. Pada intinya manajemen kesiswaan disuatu sekolah membantu siswa untuk mengembangkan dirinya yang sesuai dengan program-program yang dilakukan oleh sekolah atau sekolah islam tersebut.

Hasil pendidikan dipandang bermutu jika mampu melahirkan keunggulan akademik dan ekstra kurikuler pada peserta didik yang dinyatakan lulus untuk satu jenjang pendidikan atau menyelesaikan program pembelajaran tertentu. Keunggulan akademik dinyatakan dengan nilai yang dicapai oleh peserta didik. Keunggulan ekstra kurikuler dinyatakan dengan aneka jenis ketrampilan yang dikuasai oleh peserta didik.

Prinsip pendidikan yang menyenangkan dan menggembirakan ialah prinsip pendidikan yang berkaitan dengan pemberian pelayanan manusiawi, yaitu pelayanan yang sesuai kebutuhan manusia, selalu memberikan jalan keluar dan pemecahan masalah, memuaskan, mencerahkan, menggembirakan, dan menggairahkan. Dengan prisip ini setiap anak akan merasa senang untuk belajar, timbul gairah dan minat yang tinggi, mau melaksanakan tugas-tugas yang diberikan oleh guru dengan rasa senang, betah tinggal didalam kelas selama berjam-jam serta menyayangi dan mencintai gurunya. Prinsip ini juga berkaitan dengan prinsip belajar mengajar PAIKEM, yaitu partisipatif, aktif, inovatif, kreatif, efektif, dan menyenangkan. Prinsip ini sejalan dengan firman Alloh SWT dalam al-Qur'an dan Terjemahnya (Kemenag, 2014: 434) : "Sesungguhnya kami mengutus kamu dengan membawa kebenaran sebagai pembawa berita gembira dan sebagai pemberi peringatan (Qs. Faathir (35):24)".

Berdasarkan pengamatan awal, Madarasah Tsanawiyah Negeri (MTsN) Sambirejo adalah Madrasah Tsanawiyah satu-satunya sekolah menengah tingkat pertama yang berbasis Islami yang berada di desa Sambirejo kecamatan Bangorejo. Madarasah ini berdiri sejak tahun 1970. Dari tahun ke tahun MTsN Sambirejo menunjukkan perkembangan yang cukup pesat. Hal ini ditunjukkan dari bertambahnya murid pada setiap tahun ajaran baru. Selain 
itu di sekolah ini juga membebaskan biaya sekolah bagi siswa yang kurang mampu. Oleh karena itu, saat ini MTsN Sambirejo mejadi salah satu pilihan orang tua untuk menyekolahkan putra putrinya. Akan tetapi, dari pengamatan penulis saat melakukan praktik kerja lapangan integratif (PKLI) di MTsN Sambirejo pada tanggal 5 januari sampai 20 februari penerapan manajemen kesiswaan tidak diterapkan dengan maksimal, sehingga mempengaruhi hasil belajar.

Adapun masalah penelitian yang ditemukan sebagai berikut: (1) dalam hal perencanaan siswa, WKS. Kesiswaan tidak menerapkan manajemen kesiswaaan dengan baik, terbukti dengan tidak menerapkan standarnisasi jumlah siswa di dalam kelas, sehingga hasil belajar di dalam kelas tidak bisa maksimal; (2) dalam penerimaan siswa baru, WKS. Kesiswaan tidak menerapkan manajemen kesiswaan dengan baik, terbukti dalam penerimaan siswa baru sekolah tidak menentukan kualifikasi tertentu terhadap penerimaan siswa baru, mengakibatkan sekolah tidak mampu menampung siswa yang sudah terdaftar sehingga mempengaruhi standarisasi jumlah dalam kelas; (3) dalam hal proses pembelajaran, WKS. Kesiswaan tidak menerapkan manajemen kesiswaan dengan baik, terbukti dalam pembinaan disiplin dan partisipasi siswa dalam proses pembelajaran, masih ada siswa yang partisipasi/minat belajarnya kurang, sehingga mempengaruhi hasil pendidikan.

Pemaparan tersebut membuktikan bahwa penerapan manajemen kesiswaanyang baik merupakan salah satu pilihan tepat dalam menghadapi permasalahan tersebut, karena manajemen kesiswaan merupakan manajemen yang berorientasi masa depan dan berdasarkan pada analisis lingkungan internal dan eksternal yang ada pada MTsN Sambirejo. Oleh karena itulah peneliti merasa penting untuk melakukan penelitian lebih lanjut terkait tema tersebut.

\section{B. Rumusan Masalah}

Adapun permasalahan dalam penelitian ini dirumuskan sebagai berikut:

1. Bagaimana penerapan manajemen kesiswaan siswa kelas VIIIE di MTsN Sambirejo tahun pelajaran 2016/2017? 
2. Bagaimana hasil belajar mata pelajaran SKI siswa kelas VIIIE MTsN Sambirejo tahun pelajaran 2016/2017?

3. Adakah pengaruh penerapan manajemen kesiswaan terhadap hasil belajar mata pelajaran SKI siswa kelas VIIIE MTsN Sambirejo tahun pelajaran $2016 / 2017 ?$

4. Seberapa besar pengaruh penerapan manajemen kesiswaan terhadap hasil belajar mata pelajaran SKI siswa kelas VIIIE MTsN Sambirejo tahun pelajaran 2016/2017?

\section{Tujuan Peneliti}

Adapun tujuan yang ingin dicapai dalam penelitian ini adalah:

1. Untuk mengetahui penerapan manajemen kesiswaan pada siswa kelas VIIIE MTsN Sambirejo tahun pelajaran 2016/2017

2. Untuk mengetahui hasil belajar mata pelajaran SKI siswa kelas VIIIEMTsN Sambirejo tahun pelajaran 2016/2017

3. Untuk mengetahui pengaruh penerapan manajemen kesiswaan terhadap hasil belajar mata pelajaran SKI siswa kelas VIIIEMTsN Sambirejo tahun pelajaran 2016/2017

4. Untuk mengetahui besarnya pengaruh penerapan manajemen kesiswaan terhadap hasil belajar mata pelajaran SKI siswa kelas VIIIEMTsN Sambirejo tahun pelajaran 2016/2017

\section{Kajian Teori}

1. Pengertian Manajemen Kesiswaan

Ungkapan manajemen kesiswaan terdiri dari dua kata yaitu manajemen dan kesiswaan. Manajemen berasal dari kata to manage yang berarti mengatur, mengelola, atau mengurusi. Terry dalam Hasibuan (2014 : 165), memberikan definisi manajemen sebagai berikut. "Management is a distinc process consisting of planing, organizing, actuating, and controling, performed to determine and accoplish statedopjectives by the use of human being and other resourse”. (Manajemen adalah proses yang terdiri dari perencanaan, pengorganisasian, penggerakan dan pengawasan 
yang dilakukan untuk mencapai tujuan yang telah ditetapkan dengan menggunakan tenaga manusia dan sumber daya lainnya). Sedangkan menurut H. Koontz \& O’Donnel, dalam Suwarno (2014 : 165), mengemukakan definisi manajemen sebagai berikut: "Management involes getting thing done through and with people". (manajemen berhubungan dengan pencapaian sesuatu tujuan yang dilakukan melalui dan dengan orang lain).

Sementara itu yang dimaksud dengan kesiswaan adalah segala sesuatu yang menyangkut dengan peserta didik atau yang lebih populer dengan istilah siswa. Dengan demikian manajemen kesiswaan memiliki pengertian suatu proses pengurusan segala hal yang berkaitan dengan siswa disuatu sekolah mulai dari perencanaan, penerimaan siswa, pembinaan yang dilakukan selama siswa berada di sekolah, sampai dengan siswa menyelesaikan pendidikannya di sekolah melalui penciptaan suasana pembelajaran yang kondusif dan kontruktif terhadap berlangsungnya proses belajar mengajar atau pembelajaran yang efektif, dengan kata lain manajemen kesiswaan merupakan keseluruhan proses penyelenggaraan usaha kerjasama dalam bidang kesiswaan dalam rangka pencapaian tujuan pembelajaran di sekolah.Adapun manajemen kesiswaan itu sendiri memiliki tujuan mengatur kegiatan-kegiatan dalam bidang kesiswaan agar proses pembelajaran yang dilaksanakan di suatu sekolah dapat berjalan dengan lancar, tertib dan teratur sedemikian rupa sehingga apa yang menjadi tujuan utama dari suatu program pembelajaran di sekolah dapat tercapai secara optimal. Manajemen kesiswaan merupakan salah satu bidang oprasional dalam pengelolaan sekolah.

a. Prinsip-prinsip Manajemen Kesiswaan

Manajemen kesiswaan bertugas mengatur berbagai kegiatan dalam bidang kesiswaan agar proses pembelajaran di sekolah Islam berjalan dengan tertib, teratur dan lancar. Untuk mewujudkan tujuan tersebut terhadap sejumlah prinsip yang harus diperhatikan. Prinsipprinsip menurut Depdikbud dalam Sulistyorini, dan Faturohman (2014 : 169) adalah sebagai berikut: (1) Siswa harus diperlakukan sabagai 
subjek dan bukan objek, sehingga harus didorong untuk berperan serta dalam setiap perencanaan dan pengambilan keputusan yang terkait dengan kegiatan mereka; (2) Kondisi siswa sangat beragam ditinjau dari kondisi fisik, kemampuan intelektual, sosial ekonomi, minat dan seterusnya. Oleh karena itu diperlukan wahana untuk berkembang secara optimal; (3) Siswa hanya akan termotivasi belajar, bila mereka menyenangi apa yang diajarkan; (4) menurut Sulistyorini, Pengembangan potensi siswa tidak hanya menyangkut ranah kognitif tetapi juga ranah efektif dan psikomotorik.

b. Ruang Lingkup Manajemen Kesiswaan

Secara umum bidang kesiswaan sedikitnya memiliki tiga tugas utama yang harus diperhatikann, yaitu penerimaan murid baru, kegiatan kemajuan belajar, serta bimbingan dan pembinaan disiplin, Sulistyorini dan Fathurrohman (2014:170). Berdasarkan tiga tugas utama tersebut ruang lingkup manajemen kesiswaan berkaitan erat dengan hal-hal sebagai berikut:

1) Perencanaan kesiswaan

Dalam perencanaan kesiswaan ini mencakup sensus sekolah dan penentuan jumlah siswa yang di terima. Menurut Daien dalam Sulistyorini dan Fathurrohman (2014:170) Sensus sekolah pencatatan anak usia sekolah yang diperkirakan akan masuk sekolah Islamatau calon siswa.” Menurut Sulistyorini Pendataan anak uia sekolah atau calon siswa merupakan salah satu komponen penting dalam perencanaan pendidikan. Dengan data yang diperoleh dari sensus sekolah akandapat ditetapkan; a) jumblah dan lokasi; b) batas daerah penerimaan siswa suatu sekolah; c) jumblah fasilitas transportasi; d) layanan program pendidikan; e) fasilitas pendidikan bagi anak-anak cacat; f) laju pertumbuhan pendidikan khususnya anak-anak usia sekolah di sekitar sekolah.

2) Penerimaan siswa baru

Penerimaan siswa baru perlu dikelola sedemikian rupa mulai dari perencanaan penentuan daya tampung sekolah Islam atau 
jumlah siswa baru yang akan diterima, mengurangi daya tampung dengan jumlah anak yang tinggal di kelas atau mengulang. Kegiatan tersebut biasanya dikelola oleh panitia penerimaan siswa atau PSB.

Langkah langkah penerimaan siswa baru adalah sebagai berikut: a) membentuk penerimaan murid; b) menentukan pendaftaran calon; c) menyediakan formulir pendaftaran; d) pengumuman pendaftaran calon; e) menyediakan buku pendaftaran; f) waktu pendaftaran; g) penentuan calon yang di terima.

Menurut Mujamil dalam Sulistyorini dan Fathurrohman (2014 : 171) dikatakan pada tahap penerimaan siswa baru, ada beberapa langkah yang perlu ditempuh yaitu: (1) promosi atau publikasi dilakukan sepanjang tahun terutama ketika ada momenmomen penting; (2) perlu membentuk group tertentu yang kuat sesuai dengan kecendrungan masarakat sekitar. Misalnya kalau mereka gemar sepak bola, maka sekolah atau madrasah sebaiknya membentuk club sepak bola yang kuat; (3) melakukan pembinaan terhadap sekolah atau madrasah di bawah yang diharapkan melakukan pembinaan terhadap sekolah atau madrasah dibawah yang diharapkan menjadi basis pemasukan siswa; (4) Menjalin hubungan yang baik dengan pemmimpin-pemimpin lembaga pendidikan di bawahnya; (5) menjalin hubungan baik dengan tokoh-tokoh kunci; (6) memberi biaya siswa bagi siswa yang berprestasi dan miSKIn; (7) bagi lembaga pendidikan yang cukup maju seharusnya mencari beberapa siswa yang sangat pandai dengan diberikan kebebasan semua iyuran bahkan mereka dberikan buku dan seragam serta peelajaran tambahan secara prifat. Mereka inilah yang diproyeksikan mampu meraih perestasi terbaik ketika Ujian Ahir Negara (UAN), cerdas cermat atau olimpiade dan; (8) sebauknya lembaga pendidikan Islam menerima siswa atau 
mahasiswa atau santri dari semua lapisan intelek tual,sosial,dan budaya meSKIpun masing-masing lapisan perlu dibatasi.

3) Proses pembelajaran

Tahapan ini berlangsung ketika siswa benar-benar telah di terima di pendidikan Islam. Pada proses pembelajaran tersebut manajemen kesiswaan harus mempersiapkan langkah lanjutan. Ada beberapa langkah yang perlu ditempuh yaitu : (a) pengelompoan siswa/mahasiswa/santri secara homogen dan heterogen; (b) penentuan program belajar; (c) penentuan setrategi pembelajaran; (d) pembinan disiplin dan partisipasi siswa dalam proses pembelajaran; (e) pembinaan kegiatan ektra kurikuler; dan (f) penentuan kenaikan kelas dan atau nilai prestasi belajar.

2. Pengertian Hasil Belajar

Menurut Sudjana dalam Saniah(2016 : 8) hasil belajar adalah kemampuan yang dimilki siswa setelah ia mengalami belajar. Sedangkan Menurut, Alwi dalam Yusuf (2009 : 3) menyampaikan "hasil" berarti sesuatu yang diadakan (dibuat, dijadikan) oleh suatu usaha, sedangkan "belajar" adalah belajar merupakan perubahan yang terjadi dalam diri seseorang setelah melalui proses.

3. Macam-macam Hasil Belajar

a. Kognitif

Kognitif merupakan cara yang dipakai siswa secara aktif dalam proses mengkontruksi makna. Kognitif dalam pembelajaran menurut Aderson dan Krathwohl dalam Widoyoko (2014 : 30) dibagi menjadi enam jenjang mulai dari jenjang yang paling rendah ke jenjang yang paling tinggi, yaitu mengingat, memahami, mengaplikasikan, menganalisis, mengevaluasi, dan mencipta.

b. Afektif

Ranah efektif adalah ranah yang berkaitan dengan sikap dan nilai. Ranah efektif mencakup watak perilaku seperti perasaan, minat, sikap, emosi, dan nilai. Ranah efekti menurut Krathwohl, Bloom dan maisa dalam Widoyoko (2014 : 41) dibedakan menjadi lima jenjang, 
Jurnal Darussalam; Jurnal Pendidikan, Komunikasi dan Pemikiran Hukum Islam

Vol. IX, No 1: 184-197. September 2017. ISSN: 1978-4767 (Cetak), ISSN: 2549-4171 (Online)

dari jenjang yang dasar atau sederhana sampai jenjang yang kompleks: yaitu: (1)recivieng/attendin; (2) responding; (3) valving; (4) organitation; and (5) characterization by evalue or calue complex.

c. Psikomotor

Cara yang dipandang untuk mengevaluasi keberhasilan belajar yang berdimensi psikomotor adalah observasi. Observasi (Widoyoko, 2014: 64) dalam hal ini biasa diartikan sebagai pengamatan dan pencatatan secara sistematik terhadap unsur-unsur yang nampak dalam suatu gejala pada objek pengukuran.

\section{E. Metode penelitian}

Jenis Penelitian ini deskriptif kuantitatif. Populasi yang digunakan dalam penelitian ini bersifat penelitian populasi karena jumlah subjek kurang dari 100 . Teknik Pengumpulan Data yang digunakan adalah observasi, angket dan dokumentasi. Validitas data menggunakan rumus korelasi product moment. Reliabilitas data menggunakan rumus Alpha. Uji normalitas data menggunakan rumus Kolmogorof Smirnov.Analisis data menggunakan rumus regresi linier sederhana

\section{F. Pembahasan}

1. Pengaruh Manajemen Kesiswaan (X)

Sesuai dengan apa yang diuraikan pada bagian sebelumnya bahwa permasalahan pertama yang dipertanyakan dalam penelitian ini adalah bagaimana penerapan manajemen kesiswaan MTsN Sambirejo Banyuwangi tahun pelajaran 2016/2017, maka hasil penelitian ini menunjukkan bahwa Berdasarkan uji t diperoleh hasil hitung manajemen kesiswaan (X) sebesar 2,707 dibandingkan t tabel dengan $\mathrm{N}=33-2$ taraf signifikansi 5\% = 2,042 dan t tabel dengan $\mathrm{N}=33-2$ taraf signifikansi $1 \%$ $=2,750$, menghasilkan hasil uji t hitung $>\mathrm{t}$ tabel, maka Ha diterima, jadi hasil penelitian ini menunjukkan bahwa manajemen kesiswaan yang diterapkan MTsN Sambirejo Banyuwangi tahun ajaran 2016/2017 tergolong kurang. 
2. Hasil Belajar siswa mat pelajaran SKI (Y)

Sesuai dengan apa yang diuraikan pada bagian sebelumnya, bahwa permasalahan kedua yang dipertanyakan dalam penelitian ini adalah hasil belajar MTsN Sambirejo Banyuwangi tahun pelajaran 2016/2017, maka hasil penelitian ini menunjukkan bahwa Berdasarkan uji t diperoleh hasil hitung variabel hasil belajar (Y) sebesar 8,096 dibandingkan $t$ tabel dengan $\mathrm{N}=33-2$ taraf signifikansi 5\% = 2,042 dan t tabel dengan $\mathrm{n}=33-2$ taraf signifikansi $1 \%=2,750$, menghasilkan hasil uji t hitung > t tabel, maka Ha diterima, jadi hasil penelitian ini menunjukkan bahwa manajemen kesiswaan yang diterapkan MTsN Sambirejo Banyuwangi tahun pelajaran 2016/2017 tergolong kurang.

3. Pengaruh Manajemen Kesiswaan (X) terhadap Hasil Belajar mata pelajaran SKI (Y)

Hasil penelitian menunjukkan bahwa manajemen kesiswaan (X) mempunyai pengaruh yang kurang terhadap hasil belajar (Y) sebesar $19,1 \%$, kurangnya 80,9\% dipengaruhi oleh variabel lain.

\section{G. Kesimpulan}

Berdasarkan hasil penelitian dan analisis data sebagaimana diuraikan pada bab sebelumnya dapat disimpulkan sebagai berikut:

1. Berdasarkan uji t diperoleh hasil hitung manajemen kesiswaan (X) sebesar 2,707 dibandingkan $\mathrm{t}$ tabel dengan $\mathrm{N}=33-2$ taraf signifikansi 5\% $=2,042$ dan $\mathrm{t}$ tabel dengan $\mathrm{N}=33-2$ taraf signifikansi $1 \%=2,750$, menghasilkan hasil uji $\mathrm{t}$ hitung > $\mathrm{t}$ tabel, maka Ha diterima, jadi hasil penelitian ini menunjukkan bahwa manajemen kesiswaan yang diterapkan MTsN Sambirejo Banyuwangi tahun ajaran 2016/2017 tergolong kurang.

2. Berdasarkan uji $\mathrm{t}$ diperoleh hasil hitung hasil belajar (Y) sebesar 8,096 dibandingkan $\mathrm{t}$ tabel dengan $\mathrm{N}=33-2$ taraf signifikansi 5\% =2,042 dan $\mathrm{t}$ tabel dengan $n=33-2$ taraf signifikansi $1 \%=2,750$, menghasilkan hasil uji $\mathrm{t}$ hitung $>\mathrm{t}$ tabel, maka Ha diterima, jadi hasil penelitian ini menunjukkan bahwa manajemen kesiswaan yang diterapkan MTsN Sambirejo Banyuwangi tahun pelajaran 2016/2017 tergolong kurang. 
3. Berdasarkan hasil uji $\mathrm{f}$ diperoleh hasilbahwa $\mathrm{F}$ hitung yaitu, 7.328 dibandingkan $\mathrm{t}$ tabel dengan $\mathrm{N}=33-2$ taraf signifikansi $5 \%=4,17$ dan $\mathrm{t}$ tabel dengan $\mathrm{N}=33-2$ taraf signifikansi $1 \%=7,56$ menghasilkan hasil uji $\mathrm{f}$ hitung > f tabel, maka Ha diterima, yang berarti variabel bebas, yaitu manajemen kesiswaan (X) secara simultan atau bersama-sama memiliki pengaruh kurang terhadap variabel hasil belajar (Y).

4. Berdasarkan hasil analisis regresi diketahui bahwa nilai $\mathrm{R}$ atau koefisien korelasi sebesar 0,437 sedangkan nilai R Square atau koefisien determinasi (KD) hasil pengkuadratan nilai $\mathrm{R}$ sebesar 0,191 yang dapat diartikan bahwa variabel bebas $\mathrm{X}$ memiliki pengaruh kontribusi sebesar $19,1 \%$ terhadap variabel Y dan 80,9\% lainnya dipengaruhi oleh faktor-faktor lain diluar variabel $\mathrm{X}$.

Dengan demikian ada pengaruh penerapan manajemen kesiswaan terhadap hasil belajar mata pelajaran SKI MTsN Sambirejo Banyuwangi sebesar $19,1 \%$, sedangkan kurangnya 80,9\% dipengaruhiolehvariabel lain.

\section{H. Saran}

Setelah mengetahui ada pengaruh Penerapan manajemen kesiswaan terhadap hasil belajar mata pelajaran SKI siswa kelas VIII E MTsN Sambirejo Banyuwangi semester ganjil tahun pelajaran 2016/2017, maka perlu kami sampaikan saran-saran sebagai berikut:

1. Manajemen Kesiswaan hendaknya meningkatkan efektifitas Hasil Belajar, karena signifikansi hasil belajar yang diberikan WKS. Kesiswaan, sesuai hasil penelitian, semakin baik hasil belajar siswa yang diberikan WKS. Kesiswaan maka semakin baik pula prestasi belajar siswa

2. Siswa hendaknya meningkatkan hasil belajarnya, karena sesuai hasil penelitian, semakin tinggi hasil belajar siswa, maka semakin tinggi prestasi belajar siswa

3. Sesuai hasil penelitian yang menyebutkan adanya pengaruh WKS. kesiswaan terhadap hasil belajar siswa, maka diharapkan pengelola sekolah, dalah hal ini khususnya WKS. kesiswaan diharapkan untuk terus 
Jurnal Darussalam; Jurnal Pendidikan, Komunikasi dan Pemikiran Hukum Islam

Vol. IX, No 1: 184-197. September 2017. ISSN: 1978-4767 (Cetak), ISSN: 2549-4171 (Online)

memberikan bimbingan kepada siswa-siswinya, karena dari hasil belajar yang baik tersebut terbukti dapat meningkatkan prestasi belajar siswa.

4. Bagi peneliti selanjutnya untik meneliti variabel yang mempunyai pengaruh hasil belajar mata pelajaran SKI siswa kelas VIII E MTsN Sambirejo dengan meneliti variabel selain variabel manajemen kesiswaan.

\section{Daftar Pustaka}

Ariani, Wahyu. 2003. Manajemen Kualitas Pendekatan Kualitatif. Jakarta: Ghalia Indonesia.

Arikunto, S. 2002. Prosedur Penelitian, Suatu Pendekatan Praktek. Jakarta: PT Rineka Cipta.

Arikunto, Suharsimi. 2006. Prosedur Penelitian Suatu Pendekatan Praktik. Jakarta: Rineka Cipta

Eko Putro Widoyoko. 2014. Penilaian Hasil Pembelajaran Di Sekolah. Yogyakarta: Pustaka Pelajar.

Daien. 1996. Pengelolaan Kesiswaan. Malang: IKIP Malang.

Djarwanto. 1984. Pokok-pokok Metode Riset dan Bimbingan Teknis Penulisan Penelitian. Yogyakarta: Liberty.

Faisal S. 1995. Format-format Penelitian Sosial, Dasar-dasar dan Aplikasi. Penerbit PT. Raja Grafindo Persada.

Fathurrohman dan Sutikno. 2007. Strategi Belajar Mengajar. Bandung: Refika Aditama.

Hasibuan Malayu.sp. 2003. Manajemen: Dasar, Pengertian, dan Masalah. Jakarta: Bumi Aksara.

Handayaningrat. 1990. Pengamtar Studi Ilmu Administrasi dan Manajemen, Cet ke10. Jakarta: Haji Mas Agung.

LAN RI, System Analysis.

Mardalis. 2008. Metode Penelitian: Suatu Pendekatan Proposal. Jakarta: Bumi Aksara.

Malayu. 2001. Manajemen Dasar, Pengertian dan Masalah. Jakarta: Bumi Aksara.

Margono. 2004. Metodologi Penelitian Pendidikan. Jakarta: Rineka Cipta.

Margono, S. 2010. Metode Penelitian Pendidikan. Jakarta: Rineka Cipta.

Marzuki. 2000. Metologi Riset, Yogyakarta: BPFE-UII.

Mulysa. 2005. Manajemen Berbasis Sekolah: Konsep Strayegi dan Implementasi. Bandung: Remaja Rosda Karya.

Mujamil. 2008. Manajemen Pendidikan Islam: Strategi Baru Pengelolaan Lembaga Pendidikan Islam. Jakarta: Erlangga.

Mujib dan Mudzakir. 2005. Ilmu Pendidikan Islam. Jakarta: Kencana.

Saniah. 2016. Pengaruh Kedisiplinan Terhadap Hasil Pembelajaran Siswi Kelas VIII Smp Mukhtar Syafaat Blokagung Tegalsari Banyuwangi Tahun Pelajaran 2015/2016. Disetasi tidak Diterbitkan. Blokagung: Program Pascasarjana IAIDA Blokagung Banyuwangi. 
Jurnal Darussalam; Jurnal Pendidikan, Komunikasi dan Pemikiran Hukum Islam

Vol. IX, No 1: 184-197. September 2017. ISSN: 1978-4767 (Cetak), ISSN: 2549-4171 (Online)

Sardirman. 1996. Interaksi \& Motivasi Belajar Mengajar. Jakarta: Raja Grafindo Persada.

Shulhan Muwahid, dan Soim. 2013. Manajemen Pendidikan Islam: Strategi Dasar Menuju Peningkatan Mutu Pendidikan Islam. Yogyakarta: Teras.

Sugiono. 2016. Metode Penelitian: Kuantitatif, Kualitatif dan R\&D. Bandung: Alfabeta.

Sugiyono. 2009. Metode Penelitian Kuantitatif dan Kualitatif. Bandung: CV. Alfabeta.

Sulistyorini, dan Fathurrohman. 2014. Esensi Manajemen Pendidikan Islam. Yogyakarta: Teras.

Sulistyorini. 2006. Manajemen Pendidikan Islam. Surabaya: ELKAF. 